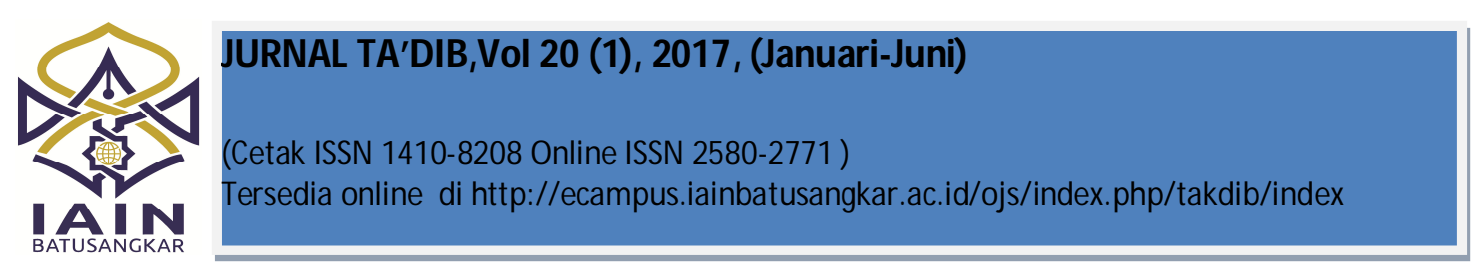

\title{
The Contribution of Teachers' Personal Relationship and Their Perception of Supervision Implementation Toward Work Achievement Motivation
}

\author{
Fitriadi Lubis*) \\ Dosen IAIN Padangsidimpuan, Indonesia \\ Email: fitriadilubis@yahoo.co.id
}

\begin{abstract}
Abstrak: The purpose of this research is to examine the relationship between teachers' interpersonal relationship and their perception about supervision implementation and their contribution toward their work achievement motivation. The data were obtained from 55 teachers as the sample by stratified proportional random sampling. The data were analyzed by means of correlation and multiple regression technique. The results of this study show that the contribution of interpersonal relationship variable was $28 \%$ to work achievement. Meanwhile, the teachers' perception of supervision implementation variable contributes $17 \%$ to work achievement motivation variable. The contribution of the two dependent variables was $41 \%$ to work achievement motivation variable.
\end{abstract}

Key Word : Interpersonal relationship, Supevision and achievement motivation

\section{PENDAHULUAN}

Guru sebagai pelaksana pendidikan terdepan di sekolah memegang peranan penting terhadap pengembangan sumber daya manusia. Hal ini cukup beralasan sebab salah satu unsur yang paling menentukan keberhasilan pendidikan adalah guru. Betapa pun baiknya sistem persekolahan, kurikulum, sarana dan prasarana pendidikan, namun semua itu tergantung pada guru. Tanpa guru unsurunsur lain dalam pendidikan tidak akan mempunyai arti banyak. Turunnya prestasi belajar anak didik juga sangat eratkaitannya dengan kualitas, cara-cara dan motivasi kerja guru dalam melaksanakan tugasnya mengajar.

Sebahagian guru bahasa Inggris belum melaksanakan tugas dan tanggung jawabnya dengan baik seperti yang diharapkan oleh pemerintah dan masyarakat. Tidak sedikit guru yang datang terlambat ke sekolah, bahkan mangkir melaksanakan tugasnya di sekolah. Gejala-gejala di atas tampaknya dapat merupakan pencerminan rendahnya motivasi kerja guru dalam melaksanakan tugas dan tanggung jawabnya. Keadaan seperti ini dapat mengakibatkan efek negatif dan apabila tidak dicari penanggulangannya secara tepat, dapat menimbulkan kendala dalam pencapaian tujuan pembelajaran bahasa Inggris yang telah ditetapkan.

Upaya meningkatkan motivasi berprestasi kerja guru bahasa Inggris hendaknya terus dilakukan dengan berbagai jalan seperti menciptakan hubungan yang harmonis antara sesama guru. Hubungan antar pribadi sesama guru diduga sangat berpengaruh terhadap motivasi berprestasi kerja guru. Terciptanya hubungan yang harmonis antara sesama guru memungkinkan guruguru akan merasa seang melakukan tugas karena adanya saling membantu, kerja sama, dan tolong menolong. Sebaliknya kalau pada suatu waktu terjadi konflik antara sesama guru dan mereka tidak dapat memecahkannya maka guru-guru bisa bersikap apatis terhadap pekerjaannya yang pada akhirnya diduga dapat 
menurunkan motivasi berprestasi kerja guru bahasa Inggris.

Disamping itu, perbedaan persepsi guru tentang pelaksanaan supervisi diduga mempunyai pengaruh tersendiri terhadap motivasi berprestasi kerja guru. Apabila guru mempunyai persepsi bahwa pelaksanaan supervisi bertujuan member bantuan atau bimbingan untuk meningkatkan kemampuan instruksional guru maka di duga akan dapat meningkatkan motivasi kerjanya. Sbaliknya apabila guru mempunyai persepsi bahwa supervisi identik dengan alat control yakni sebagai alat untuk mencari-cari kesalahan guru semata, maka guru teresebut akan enggan dan bahkan menolak supervisi. Bila hal ini terjadi diduga dapat berpengaruh terhadap motivasi berprestasi kerhja guru.

Hubungan antar pribadi seseorang dengan orang lain merupakan bagian penting dari kehidupan manusia seharihari. Hubungan antarpribadi seseorang dengan orang lain tidak tumbuh dan terjalin begitu saja secara otomatis, tetapi berkembang melalui tahapan-tahapan tertentu. Nelson dan John (1992) mengatakan bahwa hubungan antarpribadi berlangsung tanpa spontanitas, tetapi melalui tahapan-tahapan seperti berikut: (a) tahap memulai, (b) tahap mengembangkan, (c) tahap memelihara dan (d) tahap memutuskan. Sejalan dengan itu Rahmat (1994) berpendapat bahwa hubungan antar pribadi itu terjadi melalui tahapan-tahapan: (a) pembentukan hubungan, (b) peneguhan hubungan dan (c) pemutusan hubungan. Namun menurut Nelson dan Johne (1992) bahwa beberapa hubungan itu sejak dari permulaan hingga terputus berlangsung hanya beberapa saat saja.

Di dalm suatu organisasi, tidak terkecuali organisasi apa pun, jalinan hubungan antarpribadi di kalangan guruguru di sekolah juga penting, sebab hubungan antarpribadi yang harmonis merupakan salah satu penentu efektifitas komunikasi. Hal-hal yang dapat menhambat komunikasi, kemungkinan besar dapat datasi bilamana hubungan kedua belah pihak cukup baik da harmonis. Sejalan dengan ini Taylor dan kawan-kawan sebagaimana dikutip oleh Rakhmat (1994) mengatakan bahwa banyak penyebab rintangan komunikasi hanya berakibat kecil bila terdapat hubungan baik di antara kedua belah pihak. Sebaliknya, pesan yang paling jelas, paling tegas dan paling cermat pun tidak dapat menghindari kegagalan, jika hubungan antarpribadi itu jelek.

Hubungan antarpribadi sesama guru yang harmonis di sekolah perlu dipertahankan dan ditingkatkan agar antara sesama guru dapat saling membantu dan melaksanakan tugas dan tanggung jawab mereka, baik yang berkenaan dengan tugas-tugas instruksional, maupun tugastugas sekolah lainny di luar tugas instruksional. Usaha-usaha memelihara serta meningkatkan hubungan antarpribadi yang harmonis harus mendapat perhatian semua pihak baik kepala sekolah, personil sekolah, maupun guru-guru itu sendiri, sebab hubungan antarpribadi sesama guru yang harmonis tidak hanya member kontribusi bagi guru itu sendiri tetapi juga bagi kepala sekolah, pegawai dan siswa secara keseluruhan. Salah satu kontribusinya bagi guru, kepala sekolah maupun personil sekolah adalah mereka dapat menjalin kerja sama dalam menjalankan tugas-tugas sekolah dengan baik. Sedangkan bagi siswa, karena terjadi kerja sama yang harmonis antara sesama guru dibidan instruksional maka siswa pundapat menerima pelajaran dari guru dengan baik.

Berkenaan dengan hal hubungan antarpribadi sesama guru di sekolah, telah diatur di dalam kode etik guru. Butir yang mengandung aspek hubungan antar sesama guru di dalam kode etik guru hasil kongres Persatuan Guru Republik Indonesia (PGRI) ke XIII pada tahun 1973 di Jakarta sebagaimana dikutip Purwanto (19993 : 158) tertuang dalam butir ke tujuh yang berbunyi sebagai berikut"guru 
menciptakan dan memelihara hubungan antar sesama guru baik berdasarkan lingkungan kerja maupun di dalam hubungan keseluruhan". Butir kode etik di atas berfungsi sebagai pedoman bagi guruguru dalam bergaul dan berhubungan antar sesama mereka.

Paling tidak ada tiga seksi aktivitas dimana guru saling berhubungan satu sama lain, yaitu (a) aktivitas pengembangan profesi, (b) tugas administrasi sekolah, dan (c) kerja social.

Supervisi memegang peranan yang sangat penting bagi pengembangan sikap dan perilaku guru dalam proses belajar mengajar, sebab supervisi tidak hanya bermanfaat bagi peningkatan kualitas mengajar guru itu sendiri, tetapi juga bagi efektivitas pencapaian tujuan mengajar. Tidak semua guru mempunyai persepsi baik tentang pelaksanaan supervisi. Sutisna (1980), mengatakan bahwa banyak guru yang mempersepsikan supervisi sebagai hal yang identik dengan evaluasi, atau mempersepsikan supervisi sebagai bantuan kepada guru. Supervisi bukanlah merupakan kegiatan yang perlu dihindari oleh guru. Di sebahagian Negara-negara maju, supervisi sudah merupakan suatu kebutuhan yang diperlukan guru. Bila guru membutuhkan bantuan, mereka meminta untuk didatangi oleh supervisornya. Guru-guru menyukai sepervisi. Penolakanc kepada supervisi bukan disebabkan oleh ketidaksukaan kepada supervisi melainkan kepada gaya supervisornya. Seperti yang diungkapkan Acheson (1987 : 6)

'teachers are hostile, not to supervision, but to the style of supervision they typically receive. Teacher might react positively to a supervisory style that is more responsive to their concerns and aspiration".

Pelaksanaan supervisi oleh supervisor atau kepala sekolah sebagai supervisor tidak terlepas dari dua aspek yang melatarbelakanginya. Pertama, pandangan supervisor terhadap supervisi itu sendiri. Gaffar (1992) berpendapat, para supervisor yang berpandangan bahwa pengertian supervisi adalah member penilaian terhadap pekerjaan guru-guru selama mengajar, akan memakai teknikteknik yang berbeda dalam menjalankan tugasnya dengan supervisor yang berpandangan dan berpendapat bahwa supervisi itu tidak lain dari pada member bantuan atau dorongan kepada guru untuk meningkatkan ketrampilannya di bidang pengajaran.

Aspek kedua ialah, gaya kepemimpinan supervisor (supervisor leadership style). Gaya pelaksanaan supervisi oleh supervisor tidak sama karena setiap orang mempunyai gaya kepemimpinan masing-masing yang membedakan antara seseorang dengan orang lain.

Para ahli mengatakan bahwa supervisor merupakan fasilitator, karena itu supervisor sebagai pelaksana supervisi yang bertugas memberikan bantuan maupun dorongan bagi guru-guru yang membutuhkannya harus memiliki kemampuan tertentu. Untuk itu, Cristenson dan kawan-kawan (1982 : 12) mengatakan, seseorang supervisor harus mempunyai kemampuan sebagai berikut:

"(a) motivating, (b) developing, (c) communicating, (d) leadership, (e) planning/organizing, (f) human relation, $(g)$ performance appraisal, $(h)$ disciplining, (i) decision making, ( $m$ ) functioning in the organization, (n) time management, (o) conducting meeting and $(p)$ interviewing.

Bantuan yang diberikan kepada guru seperti telah disebutkan di atas ialah bantuan dalam hal usaha meningkatkan kemampuan guru dalam bidang instruksional. Subari (1994) mengemukakan bahwa bantuan yang diberikan supervisor kepada guru yang berkenaan dengan usaha meningkatkan kualitas guru dalam aktivitas belajar mengajara, meliputi bidang-bidang sebagai berikut: (a) merumuskan tujuan pengajaran, (b) mencari sumber-sumber 
pengajaran, (c) memilih buku pengajaran, (d) persiapan pengajaran, (e) memahami metodologi pengajaran, (f) menggunakan alat peraga dan, (g) mengevaluasi hasil belajar siswa.

Motivasi berprestasi kerja sangat pen-ting dimiliki oleh setiap individu di dalam organisasi, sebab menurut Hersey dan Blanchard (1988), individu-individu atau orang-orang yang memiliki motivasi berprestasi kerja bisa menjadi tulang punggung bagi organisasi. Mereka dapat mempengaruhi produktivitas organisasi, untuk itu motivasi berprestasi kerja hendaknya tetap dipelihara dan diusahakan agar tidak menurun apalagi hilang. Anogoro (1992) berpendapat bahwa, kuat lemahnya motivasi kerja seseorang ikut menentukan besar kecilnya prestasi kerjanya. Kutipan di atas dapat member pengertian bahwa bila motivasi berprestasi kerja seseorang rendah maka prestasi kerjanya pun cenderung rendah. Sebaliknya motivasi berprestasi kerja sesorang tinggi maka prestasi kerjanya pun cenderung tinggi pula.

Sikap orang yang memiliki motivasi berprestasi kerja tidak sama dengan orang yang tidak memilikinya. Orang yang memiliki motivasi berprestasi kerja yang tinggi cenderung lebih menyukai dan mencintai pekerjaan, lebih bertanggung jawab dan lebih merasa menyatu dengan pekerjaannya dari pada orang yang memeiliki motivasi berprestasi kerja yang rendah. Ini mungkin disebabkan oleh apa yang mereka cari dari pekerjaan mereka tidak sama. Dalam halini menurut Mingkor yang dikutip oleh Warta Ekonomi (2001), dalam salah satu penelitian di sejumlah perusahaan multinasional Amerika, ada sepuluh hal utama yang dicari orang yang memiliki motivasi berprestasi dalam pekerjaannya, yaitu (a) dia bekerja dengan orang memperlakukan sesama dengan respek, (b) pekerjaan memang menarik, (c) pengakuan atas prestasi yang baik, (d) ada kesempatan untuk mengembangkan ketrampilan, (e) bekerja dengan orang yang mau mendengarkan gagasan mengenai bagaimana melakukan sesuatu dengan baik, (f) kesempatan untuk berfikir tentang diri sendiri ketimbang hanya melakukan instruksi saja, (g) dia dapat melihat hasil akhir dari pekerjaannya, (h) bekerja dengan pemimpin yang efisien, (i) pekerjaannya tidak terlalu mudah, dan (j) merasa diberi informasi mengenai perkembangan yang ada.

Guru sebagai pelaksana terdepan kegiatan sekolah mengemban tugas dan tanggung jawab yang sangat berat terhadap profesinya. Tugas dan tanggung jawab guru tidak hanya sekedar menyampaikan materi pelajaran belaka di depan kelas, setelah itu ia pulang, akan tetapi lebih dari itu. Cooper dan kawan-kawan sebagaimana dikutip Bafadal (1992) mengatakan bahwa tugas guru di sekolah adalah (a) merencanakan, (b) mengimplementasikan dan (c) menilai pengajaran. Masih dalam hal yang sama Ahmadi dan Supriyono (1993) berpendapat bahwa dengan perkembangan ilmu pengetahuan dan teknologi yang disertai dengan perkembangan social budaya yang berlangsung pesatnya. Peranan guru telah meningkat dari sebagai pengajar menjadi pembimbing. Maka yang menjadi tugas dan tanggung jawab guru adalah (a) merencanakan, (b) melaksanakan pengajaran, (c) mengevaluasi dan , (d) membimbing siswa.

Berdasarkan uraian di atas ada tiga hipotesis yang diajukan dalam penelitian ini. Prtama, terdapat hubungan yang signifikan antara hubungan antarpribadi sesame guru dengan motivasi berprestasi kerjanya. Kedua, terdapat hubungan yang signifikan antara persepsi guru tentang pelaksanaan supervisi dengan motivasi berprestasi kerjanya. Ketiga, terdapat hubungan yang signifikan antara hubungan antarpribadi sesame guru dan persepsi guru tentang pelaksanaan supervisi secara bersama-sama dengan motivasi berprestasi kerjanya. 


\section{METODE PENELITIAN}

Populasi penelitian ini dalah guruguru bahasa Inggris SMA kota Padangsidimpuan. Sampel penelitian ini sebanyak 55 orang. Pengambilan sampel dilakukan melalui suatu prosedur proportional stratified random sampling. Pengumpulan data dilakukan dengan menggunakan angket.

Sebelum melakukan pengujian hipotesis, terlebih dahulu dilakukan pengujian persya-ratan analisis yaitu; uji normalitas dengan teknik Chi kuadrat. Untuk pengujian hipotesis digunakan uji " $t$ " dan uji " $F$ ". Keseluruhan analisis tersebut di atas dikerjakan dengan alat bantu computer. Program yang digunakan adalah pake "SPSS"

\section{HASIL DAN PEMBAHASAN}

Untuk melihat apakah terdapat hubungan antara variable hubungan antarpribadi sesama guru $\left(\mathrm{X}_{1}\right)$ dengan motivasi berprestasi kerja (Y) digunakan analisis korelasi sederhana. rangkuman hasil analiss korelasi dan uji keberartian korelasi tersebut dapat dilihat pada table 1

Tabel 1. Rangkuman hasil analisis korelasi dan uji t variable $\mathrm{X}_{1}$ dengan $\mathrm{Y}$.

\begin{tabular}{|c|c|c|c|c|}
\hline \multirow{2}{*}{$\begin{array}{c}\text { Korel } \\
\text { asi }\end{array}$} & \multirow{2}{*}{$\begin{array}{c}\text { Koefisien } \\
\text { Korelasi } \\
\text { (r) }\end{array}$} & \multirow{2}{*}{$\begin{array}{l}\text { Koefisi } \\
\text { en } \\
\text { Determ } \\
\text { inasi } \\
\left(\mathrm{R}^{2}\right)\end{array}$} & \multicolumn{2}{|c|}{ Signifikansi } \\
\hline & & & $\mathrm{t}_{\text {hit }}$ & $\mathrm{t}_{\mathrm{tab}}$ \\
\hline $\mathrm{r}_{\mathrm{y} 1}$ & 0,53 & 0,28 & 6,491 & 1,980 \\
\hline
\end{tabular}

Table 1. di atas memperlihatkan bahwa koefisien korelasi antara variabl $\mathrm{l}_{\mathrm{e}} \mathrm{X}_{1}$ dengan $\mathrm{Y}$ adalah positif dengan koefisien korelasi $\left(r_{y 1}\right)=0,53$. Kekuatan hubungan ditunjukkan dengan determinasi $\left(\mathrm{R}^{2}\right)=$ 0,28 . Setelah diuji " $t$ " diperoleh $t$ hitung lebih besar dari $\mathrm{t}_{\text {table. }}$. Hal ini menunjukkan bahwa korelasi antara variable $\mathrm{X}_{1}$ dengan Y adalah signifikan.

Koefisien korelasi seharga 0,53 pada taraf alpha 0,05, menunjukkan bahwa variasi yang terjadi pada $\mathrm{Y}$ sebesar $28 \%$ dapat ditentukan oleh variable $\mathrm{X}_{1}$. hal ini berarti hipotesi pertama yang diajukan dalam penelitian ini dapat diterima.

Hubungan dan besarnya pengaruh antara persepsi guru tentang supervisi $\left(\mathrm{X}_{2}\right)$ terhadap motivasi berprestasi kerja (Y) dapat juga diketahu dengan menngunakan analis korelasi sederhana. Rangkuman hasil analiss korelasi dan uji keberartian korelasi tersebut dapat dilihat pada tabel 2

Tabel 2. Rangkuman hasil analisis korelasi dan uji t variable $X_{2}$ dengan $Y$

\begin{tabular}{|c|c|c|c|c|}
\hline Korel & Koefisi & Koefisien & \multicolumn{2}{|c|}{ Signifikansi } \\
\cline { 4 - 5 } & $\begin{array}{c}\text { en } \\
\text { Korelas } \\
\mathrm{i}(\mathrm{r})\end{array}$ & $\begin{array}{c}\text { Determinasi } \\
\left(\mathrm{R}^{2}\right)\end{array}$ & $\mathrm{t}_{\text {hit }}$ & $\mathrm{t}_{\text {tab }}$ \\
\hline $\mathrm{r}_{\mathrm{y} 2}$ & 0,41 & 0,17 & 4,648 & 1,980 \\
\hline
\end{tabular}

Table 2. di atas memperlihatkan bahwa $t$ hitung lebih besar dari $t$ table. Hal ini menunjukkan bahwa terdapat hubungan antara variable $\mathrm{X}_{1}$ dengan $\mathrm{Y}$. kemudian pada taraf alpha 0,05 , koefisien korelasi seharga 0,41 menunjukkan bahwa variasi yang terjadi pada variable $\mathrm{Y}$ sebesar $17 \%$ dapat ditentukan oleh variable $\mathrm{X}_{1}$. Hal ini berarti hipotesis kedua yang diajukan dalam penelitian ini dapat diterima.

Untuk melihat apakah terdapat hubungan antara variable hubungan antarpribadi sesama guru $\left(\mathrm{X}_{1}\right)$ dan persepsinya terhadap supervisi (X2) dengan motivasi berprestasi kerja (Y) dapat diketahui dengan menggunakan analisis korelasi ganda sederhana. Sedangkan analisis regresi ganda dilakukan dengan tujuan untuk mengetahui apakah hubungan itu berupa hubungan prediktif atau bukan. Rangkuman hasil analisis korelasi ganda serta uji keberartian koefisien korelasinya diperlihatkan pada table 3 .

Tabel 3. Rangkuman hasil analisis korelasi ganda dan uji $\mathrm{F}$ variable $\mathrm{X}_{1}, \mathrm{X}_{2}$ dengan $\mathrm{Y}$

\begin{tabular}{|c|c|c|c|c|}
\hline \multirow{2}{*}{$\begin{array}{c}\text { Korel } \\
\text { asi }\end{array}$} & \multirow{2}{*}{$\begin{array}{c}\text { Koefisie } \\
n \\
\text { Korelasi } \\
(\mathrm{r})\end{array}$} & \multirow{2}{*}{$\begin{array}{c}\text { Koefisien } \\
\text { Determina } \\
\text { si }\left(\mathrm{R}^{2}\right)\end{array}$} & \multicolumn{2}{|c|}{ Signifikansi } \\
\hline & & & $\mathrm{t}_{\text {hitung }}$ & $\begin{array}{c}\mathrm{t} \\
\text { tabel }\end{array}$ \\
\hline $\mathrm{r}_{\mathrm{y} 1.2}$ & 0,64 & 0,41 & 36,84 & 3,09 \\
\hline
\end{tabular}


Table 3. memperlihatkan bahwa hasil analisis koefisien korelasi ganda antara variable $\mathrm{X}_{1}, \mathrm{X}_{2}$ dengan $\mathrm{Y}$ berbentuk positif.

Uji $F$ dilakukan untuk melihat signifikansi korelasi antara kedua variable bebas dengan variable terikat. Setelah uji $\mathrm{F}$, menghasilkan $\mathrm{F}$ hiting $=36.84$ sedang $\mathrm{F}$ table $=3,09$ untuk alpha 0,05. perhitungan ini menujukkan bahwa $\mathrm{F}$ hitung lebih besar dengan $\mathrm{F}$ table. Hal ini berarti koefisien korelasi ganda tersebut signifikan.

Hasil perhitungan analisis koefisien regresi ganda ialah sebagai berikut

Tabel 4. Rangkuman hasil analisis regresi ganda dengan Uji "F"

\begin{tabular}{|c|c|c|c|c|c|}
\hline $\begin{array}{c}\text { Sum } \\
\text { ber }\end{array}$ & JK & db & RK & $\mathrm{F}_{\text {hit }}$ & $\mathrm{F}_{\text {tab }}$ \\
\hline $\begin{array}{c}\text { Regr } \\
\text { esi }\end{array}$ & $2,213.41$ & 2 & $1,106.71$ & 36,84 & 3,09 \\
\hline $\begin{array}{c}\text { Resid } \\
\mathrm{u}\end{array}$ & $3,188.09$ & 107 & 29.80 & - & - \\
\hline Total & $5,401.50$ & 109 & - & - & - \\
\hline
\end{tabular}

Tabel 4. Di atas menginformasikan bahwa $\mathrm{F}$ hitung $=36,84$ sedangkan $\mathrm{F}$ tabel $=3,09$ untuk alpha 0,05. F hitung lebih besar dar $F$ table. Hal ini berarti persamaam regresi ganda tersebut diterima. Artinya terdapat hubungan yang signifikan antara variable $\mathrm{X}_{1}$ dan $\mathrm{X}_{2}$ secara bersama-sama dengan variabel $\mathrm{Y}$. dari hasil perhitungan tersebut di atas dapat juga ditarik kesimpulan bahwa variable $\mathrm{X}_{1}$ dan $\mathrm{X}_{2}$ secara bersama-sama dapat digunakan untuk meramalkan atau memprediksi tingkat motivasi berprestasi kerja guru. Hipotesi ketiga yang diajukan dalam penelitian ini berarti dapat diterima.

\section{Pembahasan}

Hasil penelitian ini menunjukkan bahwa ketiga hipotesis penelitian ini dapat diterima, baik secara sendiri-sendiri maupun bersama-sama. Asumsi-asumsi yang mendasari pengkajian tesori ternyata didukung oleh data empiric yang diperoleh dari responden.

Yang paling menarik dari temuan penelitian ini adalah bahwa penelitian ini relevan dengan gaya manajemen modern dewasa ini yang cenderung menuntut people centered dalam organisasi dan manusia bukan lagi semata-mata sebagai alat produksi sebagaimana halnya gaya manejemen awal-awal tahun 1930-an, melainkan sebagai factor pendorong dalam mencapai tujuan.

Dalam kaitan dengan hubungan antarpribadi ini Indrawijaya (1996) mengatakan bahwa dalam organisasiorganisasi kekar-yaan maupun profesi, hubungan antarpribadi akhir-akhir ini banyak dipelajari dan dipraktekkan di Negara-negara yang sudah maju. Salah satu contoh di PT. Toyota Astra Motor. Di dalam menilai kinerja karyawannya salah satu unsur yang diuji adalah human relation antara sesama karyawannya dan aspek yang dinilai antara lain kerja sama antara sesama karyawan (team work) dan hubungan social (social contact).

Hasil penelitian ini juga menunjukkan bahwa terdapat hubungan yang signifikan antara persepsi guru tentang pelaksanaan supervisi dengan motivasi berprestasi kerja. Robinson (1998) mengatakan $30 \%$ guru yang diteliti memerlikan bantuan supervisi dalam melaksanakan pekerjaanya.

\section{KESIMPULAN DAN SARAN}

Hubungan antarpribadi sesama guru, persepsi guru tentang pelaksanaan supervisi dan motivasi berprestasi kerja guru SMA di kota Padangsidimpuan dapat dikategorikan baik. Hasil penelitian ini mengungkapkan bahwa hubungan antarpribadi sesama guru dan persepsinya tentang pelaksanaan supervisi kepala sekolah merupakan dua factor dari factorfaktor yang dapat mempengaruhi motivasi berprestasi kerja guru dalam melaksanakan tugasnya di sekolah. Baik secara sendirisendiri maupun secara bersama-sama, hubungan antarpribadi dan persepsi tentang pelaksanaan supervisi dapat menentukan tinggi rendahnya motivasi berprestasi kerja guru. 
Saran-saran

1. Kontribusi hubungan antarpribadi sesame guru cukup signifikan terhadap motivasi berprestasi kerja guru bidang studi bahasa Inggris, karena itu kepala sekolah sebagai atasan di sekolah hendaknya dapat menciptakan hubungan yang harmonis dan akrab antar sesame guru

2. Guru bahasa Inggris sebagai ujung tombak dalam pelaksanaan pendidikan dan pengajaran bidang studi bahasa Inggris di sekolah, hendaknya saling menciptakan dan memelihara hubungan baik antara sesame guru, sesuai dengan kode etik guru.

3. Para guru hendaknya menghilangkan persepsi negatif terhadap supervisi yang dilakukan supervisor.

\section{REFERENSI}

Acheson, Keith. A. (1987). Techniques in the Supervision of Teaching. New York: Longman.

Anogoro, Panji. (1992). Psikologi Kerja. Jakarta : Rineka Cipta.

Bafadal, Ibrahim. (1992). Supervisi Pengajaran, Teori dan Aplikasinya dalam Membina Profesional Guru. Jakarta : Bumi Aksara.

Cristenson dkk. (1982). Supervising. California : Addison Wesley Publishing Company

Gaffar, MS. A. (1992). Dasar-dasar Administrasi dan Supervisi Pengajaran. Padang : Angkasa Raya.

Hersey. Paul dan Blanchard, Keith H. (1988). Management of Organizational Behavior, Utilizing Human Resources. New Jersey : Prentice hall.
Nelson, Richard dan Jhones. (1978). Human Relation Skills. Terjemahan Prihatono, R. Bagio, (1992). Cara membina hubungan yang baik dengan orang lain. jakarta : Bumi Aksara.

Purwanto, Ngalim. (1993). Administrasi dan Supervisi Pendidikan. Bandung : Remaja Rosdakarya.

Rahmat, Jalaluddin. (1994). Psikologi Organisasi. Bandung : Rosdakarya

Robinson, John J. (1998, November). ERIC Clearinghouse on Educational management. The observation Report- A help or Nuisance

Subari. (1994). Supervisi Pendidikan dalam Rangka Perbaikan Situasi mengajar. Jakarta : Bumi Aksara. 